\title{
Fecal Microbiota Transplant in a Patient Infected with Multidrug-Resistant Bacteria: A Case Report
}

\author{
Catarina Gouveia $^{\mathrm{a}}$ Carlos Palos $^{\mathrm{b}}$ Patrícia Pereira ${ }^{c}$ Lídia Roque Ramos $^{\mathrm{a}}$ \\ Marília Cravo ${ }^{a}$ \\ ${ }^{a}$ Gastroenterology Department, Beatriz Ângelo Hospital, Loures, Portugal; ${ }^{b}$ Infection Control and \\ Antimicrobial Resistance Department, Beatriz Ângelo Hospita, Loures, Portugal; ' Microbiology Department, \\ Beatriz Ângelo Hospital, Loures, Portugal
}

\section{Keywords}

Fecal microbiota transplantation · Multidrug-resistant bacteria $\cdot$ Recurrent cholangitis

\section{Abstract}

Introduction: There has been a growing interest in fecal microbiota transplantation (FMT) as a way to manipulate gut microbiota, with potential benefit in patients infected with multidrug-resistant (MDR) bacteria. Case Presentation: We present the case of an 87-year-old male with recurrent ascending cholangitis due to biliary atony and impaired biliary drainage after multiple biliary sphincterotomies and two papillary balloon dilations. In this context, a choledochoduodenostomy was performed, but the patient kept on having repeated episodes of acute cholangitis, resulting in multiple hospitalizations, every other week, with need of multiple broad-spectrum antibiotic courses, which led to bacteremias with MDR microorganisms. Several therapeutic strategies such as prophylactic antibiotics (including rifaximin), pre- and probiotics, prokinetics, and ursodeoxy- cholic acid were unsuccessfully attempted. After multidisciplinary case discussion, an FMT was proposed, with the aim of manipulating gut microbiota and decreasing MDR bacteremias. We first performed FMT via colonoscopy in September 2018, after which the patient still had 3 more hospitalizations for acute cholangitis, but isolated bacteria in blood cultures were resistant only to amoxicillin and clavulanic acid. Considering this apparent change in the microbial resistance profile, we performed a second FMT in January 2019 via the upper gastrointestinal route. During the next 4 months, the patient remained well. In April 2019, the patient relapsed again with three more episodes of cholangitis, for which we repeated the FMT via upper gastrointestinal endoscopy. No readmissions were observed during the next 4 months. All three FMTs were performed without complications. Discussion and Conclusion: FMT seems to be a safe procedure and was effective in decreasing hospital admissions and changing the profile of MDR bacteria previously isolated from blood cultures.

(c) 2020 Sociedade Portuguesa de Gastrenterologia Published by S. Karger AG, Basel
(C) 2020 Sociedade Portuguesa de Gastrenterologia Published by S. Karger AG, Basel

\section{Karger $\stackrel{2}{=}$}

BOPEN ACCESS
This article is licensed under the Creative Commons AttributionNonCommercial-NoDerivatives 4.0 International License (CC BYNC-ND) (http://www.karger.com/Services/OpenAccessLicense). Usage and distribution for commercial purposes as well as any distribution of modified material requires written permission.
Catarina Gouveia

Gastroenterology Department, Beatriz Ângelo Hospital

Avenida Carlos Teixeira, 3

PT-2674-514 Loures (Portugal)

catarinagouveia228@gmail.com 
Transplante de microbiota fecal num doente infetado com microorganismos resistentes

\section{Palavras chave}

Transplante de microbiota fecal · Bacterias

multi-resistentes $\cdot$ Colangite recorrente

\section{Resumo}

Introdução: Tem havido um crescente interesse no transplante de microbiota fecal (TMF) como forma de manipular a microbiota intestinal, com potencial benefício em doentes infetados com microorganismos resistentes aos antibióticos (MRA). Caso Clínico: Apresentamos o caso de um homem de 87 anos de idade com colangite ascendente recorrente por atonia biliar e atraso na drenagem biliar após múltiplas esfincterotomias e duas esfincteroplastias com balão. Neste contexto, o doente foi submetido a uma coledocoduodenostomia, mantendo, no entanto, episódios recorrentes de colangite com elevada frequência ( 2 semanas), o que motivou hospitalizações múltiplas com necessidade de antibioterapia de largo-espectro, tendo como consequência bacteriémias por MRA. Várias estratégias terapêuticas, como antibioterapia profilática (incluindo rifaximina), pré e probióticos, procinéticos e ácido ursodesoxicólico, foram tentadas sem sucesso. Após discussão multidisciplinar do caso foi proposta a realização de um TMF, como forma de manipular a microbiota intestinal e diminuir as bacteriémias por MRA. Realizámos um TMF por via baixa (colonoscopia) em Setembro de 2018, após o qual o doente teve mais 3 hospitalizações por colangite, com bacteriémia a um microorganismo apenas resistente à amoxicilina e ácido clavulânico. Considerando a aparente mudança no perfil de resistência microbiana, realizamos um segundo TMF em Janeiro de 2019 por via alta (endoscopia), após o qual o doente permaneceu assintomático e sem novos internamentos durante 4 meses. Em Abril de 2019, o doente voltou a ter três episódios de bacteriémia com necessidade de internamento, pelo que repetimos a realização do TMF por via alta. O doente permaneceu sem novos internamentos durante 4 meses. Nenhum dos procedimentos teve complicações. Discussão e Conclusão: O TMF parece ser um procedimento seguro e foi eficaz na redução de internamentos hospitalares e na mudança do perfil de resistência dos microorganismos isolados nas hemoculturas.

C 2020 Sociedade Portuguesa de Gastrenterologia Publicado por S. Karger AG, Basel

\section{Introduction}

Increased prevalence of antimicrobial-resistant microorganisms is becoming a global public health problem, and one of the most important medical challenges faced by the worldwide infectious disease community [1]. In this setting, there has been a growing interest in fecal microbiota transplantation (FMT) as a way to manipulate gut microbiota. FMT is defined as a procedure where feces from a healthy donor are infused in the gastrointestinal (GI) tract of a recipient patient to treat a disease associated with alteration of the gut microbiota, in order to restore the healthy microbial flora [2]. Currently, recurrent Clostridioides difficile infection is the single formal indication where FMT has an undeniable role with a cure rate of $93.8 \%$ after one or two duodenal infusions of donor feces [3]. More recently, several published studies also reported benefit in patients with multidrug-resistant (MDR) bacteria. Bilinski et al. [4] showed that not only FMT was safe in immunosuppressed patients with hematological diseases, but it also eradicated MDR bacteria from the GI tract of this particularly vulnerable population. A Dutch group [5] treated 15 patients carrying extended spectrum beta lactamase-producing Enterobacteriaceae (ESBL-EB) with FMT with very encouraging results. Twenty percent $(n=3)$ of the patients were ESBLnegative at 1,2 , and 4 weeks after the first transplant, while $40 \%(n=6)$ were negative after the second transplant. A recently published systematic review addressed the use of FMT for decolonization and prevention of MDR infection [6]. Twenty-one studies including 192 patients were analyzed. The population was heterogenous and included particularly susceptible groups of patients (hematological disorders, cancer, and post-solid organ transplant) colonized with MRD bacteria - carbapenemresistant Enterobacteriaceae (CRE), vancomycin-resistant enterococci (VRE), ESBL-EB, and methicillin-resistant Staphylococcus aureus (MRSA). In most studies, donors were unrelated, and frozen stools were used. Upper GI endoscopy was the most frequently used route of FMT administration, and eradication rates varied between 37.5 and $87.5 \%$. Follow-up ranged from 14 to 1,200 days, and no serious adverse events were reported.

We present a case of a patient with 30 hospital admissions during a 6-year period for repeated episodes of cholangitis. The patient had undergone multiple endoscopic retrograde cholangiopancreatographies (ERCPs) with biliary sphincterotomies and two papillary balloon dilations. Due to this desperate scenario in an elderly patient infected with MDR bacteria only sensitive to me-

Fecal Microbiota Transplant and

Multidrug-Resistant Bacteria

GE Port J Gastroenterol 2021;28:56-61 
ropenem and colystin, we tried FMT with the purpose of reprograming gut microbiota and eventually reducing the number of MDR bacteremias with probable origin on the gut.

\section{Case Report and Case Presentation}

We present the case of an 87-year-old male with a history of atrial fibrillation, hypertensive heart disease, stage 3 chronic kidney disease, and undetermined monoclonal gammopathy, medicated with valsartan, bisoprolol, and apixaban. He was a nonsmoker, had no known allergies, and his family history was irrelevant. He underwent cholecystectomy in 1992 for complicated cholelithiasis. After surgery, he still had recurrent residual choledocholithiasis often complicated with acute cholangitis, leading to approximately six hospitalizations between 1993 and 2012. During this period, he underwent multiple ERCPs, which showed a dilated common bile duct with poor biliary drainage and multiple gallstones, which were removed at each instance. Since he was first admitted to our hospital in 2012, he had 12 episodes of acute cholangitis requiring hospital admission between 2012 and 2014. During these 2 years, 8 ERCPs were performed with enlargement of previous sphincterotomy and two papillary balloon dilations up to $10 \mathrm{~mm}$. Because the recurrent episodes of cholangitis remained despite successive ERCPs with stone removal, biliary atony was identified as the main problem, but we also hypothesized that biliary drainage impairment could also be present. Because of this, he underwent a side-to-side choledochoduodenostomy in May 2014. Nevertheless, after surgery, recurrent episodes of acute ascending cholangitis kept on occurring at an increased frequency, despite no evidence of biliary lithiasis or anastomotic stenosis. The patient presented with fever, chills and asthenia, normal liver function tests (after surgery), and bacteremia was documented in most instances. Biliary gallstones, anastomotic stenosis, and other infectious diseases were excluded. Upper GI endoscopy showed a patent biliodigestive anastomosis with stump dilation, making progression through biliary ducts feasible with a $12-\mathrm{mm}$ therapeutic endoscope (Fig. 1, 2). The patient underwent a hepatobiliary scintigraphy, which revealed a biliary drainage delay with intrahepatic and choledochal biliary stasis, but with complete drainage by the end of the study. Sump syndrome was excluded as the magnetic resonance cholangiopancreatography and ERCP did not show any content at the anastomosis or the common bile duct between the anastomosis and the ampulla of Vater. After discussion with the surgical team, a surgical anastomotic reconstruction was not considered an option due to the patient's advanced age and comorbidities. He had a mean of 3-5 hospitalizations per year, with a total of 30 hospital admissions between 2012 and 2018, corresponding to 353 days in hospital. During these years, several therapeutic strategies, such as prophylactic antibiotic therapy (including rifaximin), probiotics, prokinetics, and ursodeoxycholic acid were unsuccessfully attempted. In the beginning of 2018 , there was a worsening of these cholangitis episodes with six additional hospitalizations during the first 8 months, the last ones at 1- or 2-week intervals, and a need for a progressive escalation of antibiotics due to isolation of MDR bacteria in blood cultures. Resistant microorganisms isolated throughout 2018

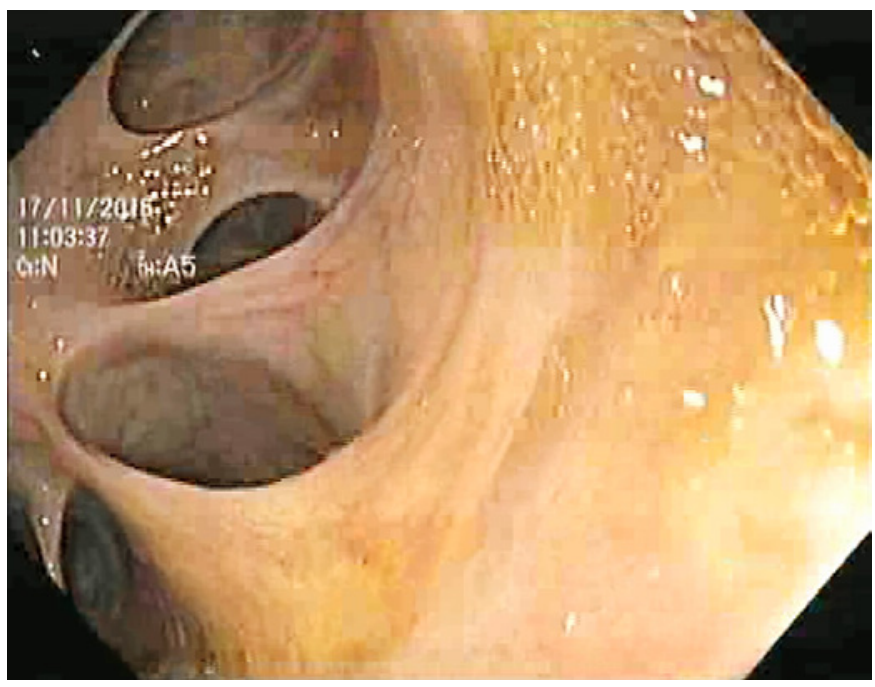

Fig. 1. Upper GI endoscopy showing a biliodigestive anastomosis with stump dilation.

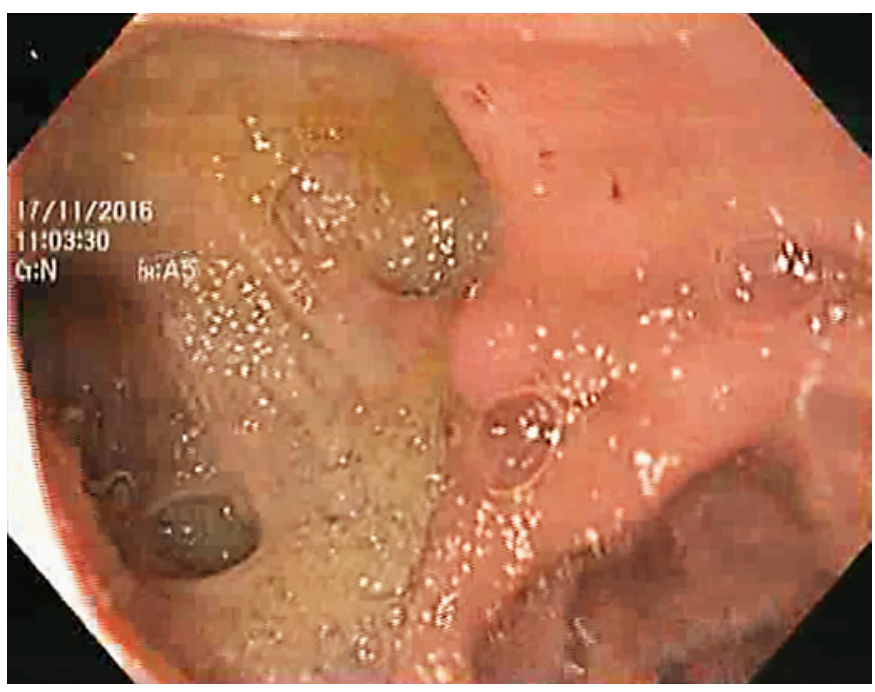

Fig. 2. Upper GI endoscopy showing a biliodigestive anastomosis with stump dilation, making progression through the biliary ducts with a therapeutic endoscope possible.

were Klebsiella pneumoniae ESBL, Escherichia coli ESBL, and K. pneumoniae CRE requiring antibiotic therapy with carbapenems, amikacin and colistin, amongst others. During the last hospitalization before FMT, an Enterobacter aerogenes only susceptible to amikacin and meropenem was grown in blood cultures. After case discussion with the Infection Control and Microbiology Committee, an FMT was proposed, aiming at manipulating gut microbiota and eventually decreasing MDR bacteria. In September 2018, we performed an FMT via colonoscopy using fresh feces $(500 \mathrm{~mL})$ from a related healthy donor (Fig. 3). The donor was the patient's niece who volunteered to donate the fecal sample. She was healthy and had infrequent contact with the patient. 

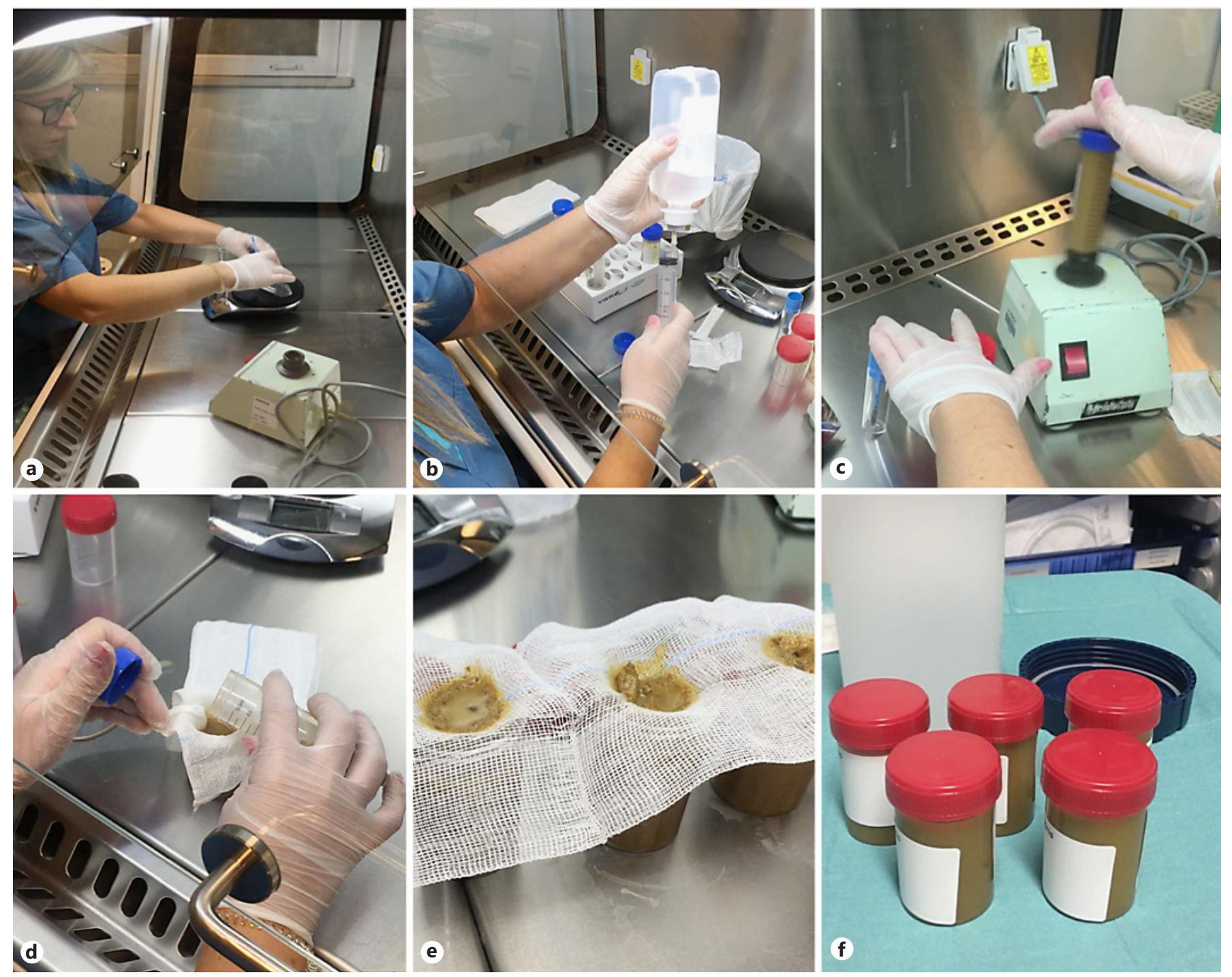

Fig. 3. Stages of fecal material processing in a level 2 biosafety unit. The stool sample is weighed (a), mixed with saline solution (b), homogenized in a vortex (c), and then filtered through a gauze to remove solid debris (d, e). Finally, the sample is stored (f) and then transferred to the endoscopy unit.

Routine blood tests were normal, and using serology she was screened for cytomegalovirus, Epstein-Barr, hepatitis A, B, C and E, human immunodeficiency virus 1 and 2, and Treponema pallidum; stool tests including C. difficile toxin, Giardia lamblia, norovirus, rotavirus, and fecal Helicobacter pylori antigen were performed. Fecal cultures for Salmonella spp., Shigella spp., Campylobacter spp., E. coli $\mathrm{OH} 157$ H7, Yersinia spp., MDR ESBL-EB, CRE, VRE and MRSA - were also excluded. Fecal occult blood test was performed as well. The patient's niece was 35 years old and had never been submitted to a colonoscopy before. After the first FMT, the patient still had 3 more hospitalizations for cholangitis, the last 2 weeks apart, but MDR bacteria were no longer isolated from blood cultures. On the first admission, a $C$. freundii resistant only to amoxicillin and clavulanic acid was isolated. The patient received piperacillin and tazobactam at all three admissions, with good responses. Considering the apparent change in the microbial resistance profile, and based on existing experience with $C$. difficile infection in which a second FMT may be required, we performed a second FMT in January 2019, this time via the upper GI route using the same donor. A total of $100 \mathrm{~mL}$ of fecal material was infused $30 \mathrm{~cm}$ below the biliodigestive anastomosis. After the second FMT, the patient remained asymptomatic and without hospitalizations for 4 months. At the end of April 2019, the patient relapsed with 3 more hospitalizations but with negative blood cultures. He was treated with piperacillin and tazobactam for 1 week in all instances. This relapse led us to repeat FMT via upper GI endoscopy with the same donor in July 2019. Four months after the last FMT and at the time of writing this paper, the patient was well and had no further episodes of ascending cholangitis. 
Discussion and Conclusion

We present the case of a patient with recurrent episodes of ascending cholangitis after cholecystectomy performed 20 years before. ERCP showed a dilated common bile duct with poor biliary drainage and multiple gallstones. Eight ERCPs with sphincterotomy and papillary balloon dilations were performed on multiple occasions. Biliary atony was obviously the main problem, but we also hypothesized that biliary drainage could also play a role and a choledocoduodenostomy was performed. Unfortunately, the latter was not effective, and recurrent ascending cholangitis with bacteremias kept on occurring. During the past 6 years, the patient had been hospitalized 30 times, lately with 2 weeks between each admission, with the need for progressive antibiotic escalation due to increased frequency of MDR bacteria isolation in blood cultures. Before FMT, an E. aerogenes only susceptible to amikacin and meropenem was isolated from blood cultures. Because surgical reconstruction was not considered an option, FMT was proposed with the aim of modulating gut microbiota and eventually decreasing MDR bacteria. We performed the first FMT via colonoscopy for safety reasons, [7] with fresh feces from a related donor who was submitted to extensive screening. After the first FMT, the patient was still admitted with fever thrice, but we noticed a change in his microbial resistance profile. On the first hospitalization after FMT, a Citrobacter freundii was isolated from blood cultures, resistant only to amoxicillin and clavulanic acid. Due to the existing experience with Clostridioides difficile infection in which a second FMT is sometimes required [3], we performed a second FMT, this time using the upper GI route. After this, the patient remained asymptomatic and without hospitalizations for 4 months. The upper route was used since previous studies showed its efficacy [7], and we were aiming at changing gut microbiota mainly in the upper GI tract. This also avoided a bowel preparation in this elderly and fragile patient. After these 4 months, he relapsed again, but it is worth noting that at this point no agent was isolated in blood cultures, and he was treated with piperacillin and tazobactam for 1 week. Together with the patient and his relatives, we decided to repeat FMT using the upper GI route again. At 4 months of follow-up, he is asymptomatic and without further readmissions. All FMT procedures were performed without complications.

In this patient, gut colonization with MDR bacteria was probably a consequence of multiple broad-spectrum antibiotic courses needed to treat multiple episodes of acute cholangitis for at least 6 years. The goal of FMT in this patient was to reprogram gut microbiota, using healthy donor feces, and consequently to reduce the number of MDR bacteremia episodes with a possible gut/biliary source. In this case, it is likely that FMT not only changed gut microorganisms' resistance profile but also increased the remission period, as the patient remained symptom free and without further hospitalizations for 4 months after the second and third FMTs. It is worth noting that before the first FMT, the patient presented with bacteremias requiring hospital admission every 1-2 weeks, and MDR bacteria were systematically isolated from blood cultures. The upper GI route may have been more efficient since the biliodigestive anastomosis was probably the source of ascending cholangitis and consequent bacteremia. Fecal material administration was performed distal to the surgical anastomosis $(30 \mathrm{~cm})$ to avoid direct biliary bacterial instillation. We can hypothesize that patient relapses after FMT are related to gut microbiota returning to its baseline after the procedure. Former gut microbiota studies show that FMT-induced microbiota alterations can last anywhere from a few days to a few years after transfer [8-10].

Despite the relative success of this case, it is important to acknowledge that pathogenic bacteria can also be introduced in the recipient, as demonstrated in the two first case reports [11] of drug-resistant E. coli bacteremia acquired after FMT, underlining the importance of a rigorous donor screening and traceability of the transplanted material.

The present case illustrates that FMT may be effective in decreasing the frequency of MDR systemic infections, even in elderly patients with several comorbidities. In the future, with growing evidence supporting the use of FMT in MDR elimination, we might consider performing FMT "on-demand" in selected patients as a decolonization strategy.

\section{Statement of Ethics}

The patient and his relatives consented to the procedure, the patient signed an informed consent form, and the procedure was approved by the Ethics Committee.

\section{Conflict of Interest Statement}

The authors have no conflicts of interest to declare.
60

GE Port J Gastroenterol 2021;28:56-61 DOI: $10.1159 / 000507263$
Gouveia/Palos/Pereira/Roque Ramos/ Cravo 


\section{Funding Sources}

There were no funding sources relevant for this study.

\section{Author Contributions}

Catarina Gouveia: acquisition and interpretation of clinical data for the case report; draft of the case report; corresponding author.
Carlos Palos: critical revision of the case report and final approval of the version to be published.

Patrícia Pereira: donor screening and fecal sample processing.

Lídia Roque Ramos: conception and design of the study, critical revision of the case report, and final approval of the version to be published.

Marília Cravo: active collaboration in patient discussion, critical revision of the case report, and final approval of the version to be published.

\section{References}

1 Fauci AS, Morens DM. The perpetual challenge of infectious diseases. $\mathrm{N}$ Engl J Med. 2012 Feb;366(5):454-61.

2 Cammarota G, Ianiro G, Tilg H, RajilićStojanović M, Kump P, Satokari R, et al.; European FMT Working Group. European consensus conference on faecal microbiota transplantation in clinical practice. Gut. 2017 Apr; 66(4):569-80.

3 van Nood E, Vrieze A, Nieuwdorp M, Fuentes S, Zoetendal EG, de Vos WM, et al. Duodenal infusion of donor feces for recurrent Clostridium difficile. N Engl J Med. 2013 Jan; 368(5):407-15.

4 Bilinski J, Grzesiowski P, Sorensen N, Madry K, Muszynski J, Robak K, et al. Fecal Microbiota Transplantation in Patients With Blood Disorders Inhibits Gut Colonization With Antibiotic-Resistant Bacteria: Results of a Prospective, Single-Center Study. Clin Infect Dis. 2017 Aug;65(3):364-70.
5 Singh R, de Groot PF, Geerlings SE, Hodiamont CJ, Belzer C, Berge IJ, et al. Fecal microbiota transplantation against intestinal colonization by extended spectrum betalactamase producing Enterobacteriaceae: a proof of principle study. BMC Res Notes. 2018 Mar;11(1):190.

6 Saha S, Tariq R, Tosh PK, Pardi DS, Khanna $S$. Faecal microbiota transplantation for eradicating carriage of multidrug-resistant organisms: a systematic review. Clin Microbiol Infect. 2019 Aug;25(8):958-63.

7 Kassam Z, Lee CH, Yuan Y, Hunt RH. Fecal microbiota transplantation for Clostridium difficile infection: systematic review and meta-analysis. Am J Gastroenterol. 2013 Apr; 108(4):500-8.

8 Weingarden A, González A, Vázquez-Baeza Y, Weiss S, Humphry G, Berg-Lyons D et al. Dynamic changes in short- and long-term bacterial composition following fecal micro- biota transplantation for recurrent Clostridium difficile infection. Microbiome. 2015 Mar; $3: 10$.

9 Broecker F, Klumpp J, Schuppler M, Russo G, Biedermann L, Hombach M, et al. Long-term changes of bacterial and viral compositions in the intestine of a recovered Clostridium difficile patient after fecal microbiota transplantation. Cold Spring Harb Mol Case Stud. 2016 Jan;2(1):a000448.

10 Kumar R, Yi N, Zhi D, Eipers P, Goldsmith KT, Dixon P, et al. Identification of donor microbe species that colonize and persist long term in the recipient after fecal transplant for recurrent Clostridium difficile. NPJ Biofilms Microbiomes. 2017 Jun;3(1):12.

11 DeFilipp Z, Bloom PP, Torres Soto M, Mansour MK, Sater MR, Huntley MH, et al. DrugResistant E. coli Bacteremia Transmitted by Fecal Microbiota Transplant. N Engl J Med. 2019 Nov;381(21):2043-50. 